Bull. Fac. Agric, Cairo Univ.,68:167-182 (2017).

\title{
IMPACT OF SOME INTEGRATED FERTILIZATION TREATMENTS ON GROWTH, PRODUCTIVITY AND QUALITY OF PEA PLANTS
}

(Received: 10.3.2017)

\author{
By \\ Sh. S. F. El-Sayed \\ Vegetable Crops Department, Faculty of Agriculture, Cairo University, Giza, Egypt
}

\begin{abstract}
Two field experiments were conducted at the Agricultural Experimental and Research Station, Faculty of Agriculture, Cairo University, Giza, Egypt, in the two winter seasons of 2013 and 2014, to investigate the effects of different fertilizer integrations, on the vegetative growth characters, green pods yield and its components and chemical contents of pea plants (Pisum sativum L.) "cv. Master B", as compared with soil mineral fertilization $(60 \mathrm{~kg} / \mathrm{fed} \mathrm{N}, 40 \mathrm{~kg} / \mathrm{fed} \mathrm{P}$ and $40 \mathrm{~kg} / \mathrm{fed} \mathrm{K})$ and chicken manure alone at 5 ton/fed. The integrated fertilization treatments included organic fertilizer (chicken manure at 5 ton/fed) with spray mineral fertilization (potassien, having 30\% $\mathrm{K}$ and $8 \% \mathrm{~N}$ ), or biofertilizations (phosphorin as phosphate dissolving bacteria, both applied to seeds and botassifag as a source of potassium dissolving bacteria) or with potassien plus phosphorien or potassifag. The experiments included eight treatments and were laid out in a randomized complete blocks design (RCBD). The obtained results indicated that the integrated fertilization management consisting of chicken manure at 5 ton/fed plus mineral foliar fertilization (using potassien) and biofertization (using potassifag or phosphorien) gave similar great effect for vegetative growth and yield to soil application of mineral N.P., K., without significant differences among them. So, the treatments of T1(soil mineral fertilization), T5 (chicken manure + potassifag + potassien) and T8 (chicken manure + phosphorien + potassien) gave greater plant fresh weight, raised $\mathrm{N}$ content in the plants and led to obtaining higher values of weight and number of pods yield per plant in both seasons, as compared with chicken manure alone (T2). Furthermore, all treatments of potassien, i.e., T5, T8 and T3 (organic fertilizer + potassien) significantly exceeded mineral fertilization in the leaf contents of chlorophyll. Also T 5 and T 8 gave significantly higher total pod yield over chicken manure alone. T 5 and $\mathrm{T} 8$ gave relatively higher values of yield per plant and per feddan than using chemical fertilizers, but without significant differences between them. T5 treatment exhibited the highest values of pod length number of seeds/pod and weight of 100 green seeds which were also significantly higher than organic manure alone. T5 and T7 (organic fertilizer + phosphorien + potassifag ) in both seasons and T8 in the first season significantly increased percentage of total sugars in green seeds as compared to chemical fertilization. Meanwhile, the integrated treatments (T5, T7 and T8) significantly increased green seeds contents of total sugars in both seasons as compared with organic fertilizer alone. T1, T3, T5 and T8 caused statistically significant increase in protein percentage over organic manure alone. The integrated fertilization management consisting of chicken manure at 5 ton/fed plus mineral foliar fertilization (using potassien) and biofertization (using potassifag or phosphorien) can be recommended for pea production in clay soil instead of using soil application of mineral fertilization with the purpose of reducing soil pollution with chemical fertilizers.
\end{abstract}

Key words: peas, integrated fertilization, biofertilization, foliar fertilization, mineral fertilization, chicken manure.

\section{INTRODUCTION}

Peas (Pisum sativum L.), a cool weather crop, is one of the most important leguminous vegetable crops grown in Egypt due to its high content of protein, carbohydrates, vitamins and minerals (Makasheva,1983). For getting high yield and 
quality of most vegetable cops, including peas, adequate supplementations of plant nutrients, especially N, P and $\mathrm{K}$, should be applied.

Nitrogen is necessary for the formation of amino acids, enzymes, chlorophyll, is the building block of protein, and is essential for plant cell division. It is vital for plant growth, through direct involvement in photosynthesis. It is also one of the necessary components of vitamins. It helps in the production and use of carbohydrates and affects energy. Phosphorus is involved in photosynthesis, respiration, energy storage and transfer, cell division and enlargement, and it promotes early root formation and growth. It improves quality of fruits, vegetables, and grains. It is vital to seed formation, helps plants survival under harsh winter conditions, increases water-use efficiency, and hastens maturity. Potassium is involved in carbohydrate metabolism, and the breakdown and translocation of starch and photoassimilates into sink organs. It increases photosynthesis and water-use efficiency. It is essential in protein synthesis and important in fruit formation. It activates enzymes and controls their reaction rates. It improves quality of seeds and fruits, and winter hardiness. It also increases disease resistance (Shukla et al., 2014)

Over the years, inorganic fertilizers have been widely used worldwide to support and optimize the growth and yield of vegetable crops. A survey in China revealed that the average rates of application of fertilizers were $780 \mathrm{~kg} \mathrm{~N}, 615 \mathrm{~kg}$ $\mathrm{P}_{2} \mathrm{O}_{5}$, and $393 \mathrm{~kg} \mathrm{~K}_{2} \mathrm{O}$ ha $^{-1}$ for obtaining the highest yield from open field vegetable crops (Chen et al., 2000). Another survey conducted in the same year in China showed that greenhouse vegetables, received much higher inputs with the application of $2388 \mathrm{~kg} \mathrm{~N}, 3,274 \mathrm{~kg} \mathrm{P}_{2} \mathrm{O}_{5}$, and 1, $216 \mathrm{~kg} \mathrm{~K}_{2} \mathrm{O} \mathrm{ha}^{-1}$ per year to get a high yield (Liu, 2000). In a comparison among three rates of $\mathrm{N}(0$, 750 and $1500 \mathrm{~kg} \mathrm{~N} / \mathrm{ha})$ and three rates of $\mathrm{K}(0$, 300 and $600 \mathrm{~kg} \mathrm{~K}_{2} \mathrm{O} / \mathrm{ha}$ ), Liu et al. (2008) found that application of $\mathrm{N}$ and $\mathrm{K}$ fertilizers substantially increased the yields of kidney bean and tomato grown in rotation under greenhouse conditions. The largest yield of kidney bean was obtained in the first and second years with the highest $\mathrm{N}$ fertilizer application rate and the intermediate rate of $\mathrm{K}$ application. However, the application of large amounts of fertilizers, a conventional practice in the world for the production of vegetable crops, generally leads to substantial accumulation of soil nutrients within a relatively short period of time. To mitigate environmental degradation, some researchers recommended organic fertilizers to improve physical, chemical and biological properties of soils and to decrease the need for inorganic fertilizers (Rizk , 2002; Francis, 2004). Organically grown foods are perceived as better quality, healthier and more nutritious than conventional counterparts (Warman and Havard, 1997). However, the relatively slow mineralization of the composts and other organic fertilizers limits the effective nitrogen utilization (Hartz et. al., 2000). The low availability of nitrogen in organic fertilizers and insufficient quantities of organically acceptable fertilizers are the main underlying factors contributing to the low yield in organic farming (Badgley et. al., 2007).

Another proposed solution to environmental and human health protection issues is the implementation of natural technologies of plant cultivation and fertilization through applications of biofertilizers. According to Malusá and Vassilev (2014), a biofertilizer is "the formulated product containing one or more microorganisms that enhance the nutrient status (the growth and yield) of the plants by either replacing soil nutrients and/or by making nutrients more available to plants and/or by increasing plant access to nutrients". Biofertilizers include microorganisms that fix nitrogen, solubilize phosphate and potassium, secret hormone and suppress soil borne plant pathogens (Mohapatra et al., 2013). Phosphate dissolving bacteria (PDB) play an important role in supplying phosphate to plants, in environment friendly and sustainable manner (Khan et al., 2007). The inoculation with PDB improved plant growth and yield of dry beans (Tozlu et al., 2012), remarkably enhanced shoot and root length, shoot and root dry matter, and $\mathrm{P}$ uptake of mung bean plants under greenhouse conditions (Walpola and Yoon, 2013), positively affected Pisum sativum L. plants grown on sandy calcareous soil (Howladar et al., 2014), and increased strawberry yield beyond the maximum achievable yield with sole P-fertilizer addition and increased fruit and leaf nutrient concentrations of $\mathrm{N}, \mathrm{P}, \mathrm{K}, \mathrm{Ca}$, and Fe (Gunes et al, 2009). Seed inoculation of cowpea with PDB helped in improvement of nodulation, root and shoot biomass, straw and grain yield and phosphorous 
and nitrogen uptake of crops (Linu et al., 2009).

The potassium solubilizing microorganisms (KSMs) are a rhizospheric microorganism which solubilizes the insoluble potassium (K) to soluble forms of $\mathrm{K}$ for plant growth and yield. Most of the farmers use only nitrogen and phosphorus and do not use the $\mathrm{K}$ fertilizer due to unawareness so that the problem of $\mathrm{K}$ deficiency occurs in rhizospheric soils. The $\mathrm{K}$ fertilizer is also costly as compared to other chemical fertilizers. Therefore, the efficient KSMs should be applied for solubilization of a fixed form of $\mathrm{K}$ to an available form of $\mathrm{K}$ in the soils. This available $\mathrm{K}$ can be easily taken up by the plant and causes enhancement for the growth and high yield (Meena et al., 2014). Inoculation of seeds and seedling treatments of plants with the KSMs generally showed significant enhancement of germination percentage, seedling vigor, plant growth, and yield and $\mathrm{K}$ uptake by plants under glasshouse and field conditions (Youssef et al., 2010; Singh et al., 2010; Awasthi et al., 2011; Zhang et al., 2013). Inoculation with KSMs have been reported to exert beneficial effects on growth and yield of eggplant (Ramarethinam and Chandra 2005; Han and Lee, 2005) pepper and cucumber (Han et al. 2006), tomato (Lin et al., 2002) and okra (Prajapati, 2013). Recently, Prajapati (2016) observed that potassium solubilizing bacteria (KSB), significantly increased seed germination, root and shoot length, number of leaves and yield of Mungebean (Vigna radiate) over uninoculated control in the presence of feldspar.

Some studies evaluated the synergistic effects of soil fertilization with rock $\mathrm{P}$ and $\mathrm{K}$ materials and co-inoculation with $\mathrm{P}$ and K-dissolving bacteria [PDB (Bacillus megaterium var. phosphaticum) and KDB (Bacillus mucilaginosus and $B$. subtilis)] on the improvement of $\mathrm{P}$ and $\mathrm{K}$ uptake, as well as $\mathrm{P}$ and $\mathrm{K}$ availability and growth of plants grown under limited $\mathrm{P}$ and $\mathrm{K}$ soil conditions (calcareous soil). In these studies, the co-inoculation of PDB and KDB in conjunction with direct application of rock $\mathrm{P}$ and $\mathrm{K}$ materials into the soil increased $\mathrm{P}$ and $\mathrm{K}$ availability and uptake, and the plant growth (shoot and root growth) of maize plants (Abou-el-Seoud and Abdel-Megeed, 2012), pepper and cucumber (Han et al., 2006) grown on $\mathrm{P}$ and $\mathrm{K}$ limited soils, suggesting their potential use as a fertilizer.
Biofertilizers may be a supplement to the organic fertilizers or it can be integrated with chemical fertilizers to reduce the cost of production and conserve soil health in vegetable plantations (El-Waraky et al., 2013). Some studies indicated that adding phosphate dissolving bacteria to chicken manure and bio-fertilizers (effective microorganism (EM) to organic fertilizer (farm yard manure) increased yield of tomato (El-Tantawy and Mohamed, 2009) and faba bean (Hellal et al., 2014), respectively, as compared to adding organic manure alone. Moreover, faba bean yield resulted from the combination between bio fertilizer and organic fertilizer was significantly higher than that gained from the use of mineral fertilizers (Hellal et al., 2014).

Foliar application of nutrients is a more suitable option compared with soil fertilization when the roots cannot provide necessary nutrients. Other advantages are quick compensation of nutrient deficiency and application of lesser rates thus, reducing toxicity arises from excessive accumulation of elements, preventing nutrients fixation in the soil and reducing problem of soil compactness (Wojcik, 2004). Foliar application is also less likely to result in ground water pollution (Hamayun et al., 2011). Foliar application of fertilizer showed excellent results in mung bean (Hamid, 1991) and lentil (Hamayun et al., 2011). Spraying $\mathrm{N}$ at flowering caused significant yield increase but application twice (at flowering and at late reproductive phase) gave significantly greater seed yield than any single application (Hamid, 1991) and the foliar application of nitrogen alone was more effective than NPK in producing higher number of seeds per lentil pod (Hamayun et al., 2011). Foliar application of potassium nitrate significantly increased vegetative growth, chlorophyll contents yield and yield components of cucumber (Al-Hamzawi, 2010) and potato (Ben Dkhil et al., 2011) as well as leaf and fruit contents of N, P and K of cucumber (Al-Hamzawi, 2010).

The objective of the present work was to study the effect of integrated fertilization, via using organic, bio- and foliar mineral fertilization, on growth, yield and fruit quality of peas. 


\section{MATERIALS AND METHODS \\ 2.1. Experimental design}

Two field experiments were conducted at the Agricultural Experimental and Research Station, Faculty of Agriculture, Cairo University, Giza, Egypt, in the two winter seasons of 2013 and 2014. The experiments included eight treatments and were laid out in a randomized complete blocks design (RCBD) with four replicates in each season. The plot area was $15 \mathrm{~m}^{2}$ and consisted of 5 rows, each $5 \mathrm{~m}$ long and $0.70 \mathrm{~cm}$ wide. Seeds of pea (cv. Master B) were sown in hills one side of the ridges at $10 \mathrm{~cm}$ apart. Three to five seeds were sown in each hill. Ten days after sowing, plants were thinned to two plants per hill. The sowing dates were $18^{\text {th }}$ and $15^{\text {th }}$ of November in the first and second seasons, respectively. The soil of experimental site was clay loam. Physical and chemical characteristics of the experimental soil at a depth of 0-30 cm are shown in Table (1).
T5. Organic fertilizer + Potassifag + Potassien.

T6. Organic fertilizer + Phosphorien.

T7. Organic fertilizer + Phosphorien + Potassifag.

T8. Organic fertilizer + Phosphorien + Potassien.

Mineral fertilizers used in the study were applied at rates of $60 \mathrm{~N} \mathrm{~kg} / \mathrm{fed}, 40 \mathrm{~kg}$ P/fed and 40 $\mathrm{kg} \mathrm{K} / \mathrm{fed}$ as is recommended for garden pea by the Ministry of Agriculture in the clay soil. Following soil preparation and ridges establishment, and before seeds sowing, phosphorus as calcium superphosphate $\left[\begin{array}{lll}15.5 \% & \mathrm{P}_{2} \mathrm{O}_{5}\end{array}\right]$, mineral-K $\quad[40$ $\mathrm{kg} / \mathrm{fed}$ as potassium sulphate $\left(48 \% \quad \mathrm{~K}_{2} \mathrm{O}\right)$ were broadcasted manually in the bottom of ridges and incorporated with the soil using a hand hoe. $\mathrm{N}$ was side banded as ammonium sulphate $(20.5 \% \mathrm{~N})$ in two equal applications, 20 and 40 days after sowing.

Chicken manure (obtained from the Agricultural Experimental and Research Station, Faculty of Agriculture, Cairo University) was

Table (1): Chemical and Physical parameters of the experimental soil.

\begin{tabular}{|c|c|c|c|c|}
\hline \multicolumn{2}{|c|}{ Chemical characteristics } & \multicolumn{3}{|c|}{ Physical characteristics } \\
\hline \multicolumn{2}{|l|}{ Character } & Value & \multirow{5}{*}{$\begin{array}{l}\text { Character } \\
\text { Coarse sand }\end{array}$} & Value \\
\hline \multicolumn{2}{|l|}{ pH } & 8.1 & & \multirow[t]{4}{*}{6.0} \\
\hline \multicolumn{2}{|l|}{ E.C (mmohs /cm) } & 0.63 & & \\
\hline \multicolumn{2}{|l|}{$\mathrm{CaCO}_{3}(\%)$} & 4.8 & & \\
\hline \multirow{3}{*}{$\begin{array}{ll}\begin{array}{l}\text { Soluble } \\
(\mathrm{meq} / \mathrm{L})\end{array} & \text { anions } \\
\end{array}$} & $\mathrm{HCO}_{3}^{-}$ & 2.8 & & \\
\hline & $\mathrm{Cl}^{-}$ & 1 & \multirow[t]{4}{*}{ Fine sand } & \multirow[t]{4}{*}{37.0} \\
\hline & $\mathrm{SO}_{4}^{-2}$ & 2.5 & & \\
\hline \multirow{4}{*}{$\begin{array}{l}\text { Soluble Cations } \\
(\text { meq/l) }\end{array}$} & $\mathrm{Ca}^{+2}$ & 1 & & \\
\hline & $\mathrm{Mg}^{+2}$ & 1.8 & & \\
\hline & $\mathrm{Na}^{+}$ & 2.6 & \multirow{3}{*}{ Silt } & \multirow[t]{3}{*}{22.0} \\
\hline & $\mathrm{K}^{+}$ & 0.57 & & \\
\hline \multirow{4}{*}{$\begin{array}{l}\text { Microelements } \\
\text { (ppm) }\end{array}$} & $\mathrm{Mn}$ & 11.6 & & \\
\hline & $\mathrm{Zn}$ & 2.46 & \multirow[t]{3}{*}{ Clay } & \multirow[t]{3}{*}{35.0} \\
\hline & $\mathrm{Cu}$ & 2.06 & & \\
\hline & $\mathrm{Fe}$ & 5.6 & & \\
\hline \multirow{3}{*}{$\begin{array}{l}\text { Macroelements } \\
(\mathbf{p p m})\end{array}$} & $\mathrm{N}$ & 121 & \multirow[t]{3}{*}{ Textural class } & \multirow[t]{3}{*}{ Clay loam } \\
\hline & $\mathrm{P}$ & 114 & & \\
\hline & $\mathrm{K}$ & 592 & & \\
\hline
\end{tabular}

\subsection{Treatments}

This experiment included 8 treatments which were:

T1. Mineral fertilizer as control.

T2. Organic fertilizer (chicken manure at a rate of 5 ton/fed.).

T3. Organic fertilizer + Potassien.

T4. Organic fertilizer + Potassifag. analyzed for total N, P and K exchangeable bases. The chemical characteristics of the chicken manure were $3.00 \% \mathrm{~N}, 0.85 \% \mathrm{P}$. and $0.65 \% \mathrm{~K}$. The amount of chicken manure was calculated according to its total nitrogen content utilized at the recommended dose of $60 \mathrm{~kg} / \mathrm{fed} \mathrm{N}$. So, chicken manure was applied at a rate of 5 ton/fed. To adjust $\mathrm{P}$ and $\mathrm{K}$ dose to be $40 \mathrm{~kg} / \mathrm{fed} \mathrm{P}$ and 40 
$\mathrm{kg} / \mathrm{fed} \mathrm{K}$ (as recommended dose of mineral fertilization in the control treatment), rock phosphates $\left(22.8 \% \quad \mathrm{P}_{2} \mathrm{O}_{5}\right)$ and feldspar $(10.6 \%$ $\mathrm{K}_{2} \mathrm{O}$ ) were applied at rates of 10 and $12 \mathrm{~kg} / \mathrm{fed}$, respectively for all chicken manure treatments. Rock phosphate and feldspar were provided by $\mathrm{Al}$ Ahram mining and natural fertilizer company in Egypt. Rock phosphate, feldspar and chicken manure were applied two weeks before seed sowing, where they were broadcasted manually in the bottom of ridges and mixed with soil using a hand hoe followed by immediate irrigation to ensure decomposition of the organic manure.

The biofertilizers, i.e., phosphorien (Bacillus megatherium; phosphate-dissolving bacteria) and potassifag (Bacillus circulance, potassiumdissolving bacteria), were provided by Agricultural Research Center, Ministry of Agriculture. The biofertilizers were used at the rate of $800 \mathrm{~g} / \mathrm{fed}$. Seed inoculation was performed by adding an adequate amount of distilled water and Arabic gum and mixed thoroughly with the seeds and inoculated just before sowing.

Potassien (provided by Agricultural Research Center, Ministry of Agriculture) contains 30\% K and $8 \% \mathrm{~N}$. It was applied as a foliar spray, 3 times at 12-day intervals, at rate of $65 \mathrm{ml} / 1$ water (as recommended by Ministry of Agriculture) starting 4 weeks after seed sowing. Few drops of Tween20 were added to the spraying solution as a wetting agent.

All other agricultural practices, such as weed control and irrigation, were conducted according to recommendations of Ministry of Agriculture, in the clay soil. All other agro-management practices for commercial production of pea were followed whenever it was necessary.

\subsection{Data recorded}

\subsubsection{Plant growth measurements}

The plant growth measurements included vegetative growth measurements, chlorophylls in leaves and $\mathrm{N}, \mathrm{P}$ and $\mathrm{K}$ concentrations in the plants. All these measurements were recorded 70 days after sowing at full blooming stage. Six plants from the two outer rows of each experimental plot were randomly chosen and pulled off from the soil for analysis and plant measurements.

For vegetative growth measurements, plant fresh weight, shoot length, number of branches/ plant were recorded.
To determine total chlorophylls, 3 different readings of chlorophyll were taken on the third top leaf of each plant, using Minolta SPAD Chlorophyll -Meter (model SPAD 501) (Yadava, 1986).

To determine $\mathrm{N}, \mathrm{P}$ and $\mathrm{K}$ concentrations in the plants, $100 \mathrm{~g}$ of represented sample of plants were oven dried at $70^{\circ} \mathrm{C}$ till a constant weight and then dry matter percentage was calculated. Dried samples were fine ground, then $0.1 \mathrm{~g}$ of each sample was digested using a mixture of sulphuric and perchloric acid as described by Peterburgski (1968), then the concentration of $\mathrm{N}$ [with Kjeldahel method as described by Hesse (1971)], $\mathrm{P}$ [spectrophotometrically according to procedures of Cottenie et al. (1982)] and K [by Flame photometric method according to Cottenie et al. (1982)] were determined.

\subsubsection{Yield and yield components measurement}

\subsubsection{Green pods yield per plant}

For green pods yield per plant determination, marketable green pod samples were harvested from ten random selected plants of the two outer rows in each plot, where weight and number of green pods were recorded.

\subsubsection{Total green pods yield per feddan}

All marketable green pods of the three inner rows, throughout the entire harvesting period, were picked and weighed to calculate the total green pods yield /fed. Green seeds were extracted and weighed to determine the total green seeds yield /fed.

\subsubsection{Green pods characteristics}

To determinate the green pods characteristics, 10 pods picked from the second harvest were chosen randomly from each plot, where pod weigh, length, and diameter as well as number of seeds per pod were recorded.

\subsubsection{Green seed quality}

To determine green seeds quality 100 grams of the green seeds were oven dried at $70{ }^{\circ} \mathrm{C}$ till a constant weight and then dry matter percentage was calculated. Dried samples were fine ground, then total sugars was determined spectrophotometrically using 5\% phenol / sulfuric acid reagent as was described in A.O.A.C. (1990). The crude protein was calculated by multiplying total nitrogen percent by the factor of 6.25 (A.O.A.C, 1990). 


\subsection{Statistical analysis}

Data of the two seasons were subjected to the statistical analysis according to Gomez and Gomez (1984) and the least significant difference test (LSD) at 5\% level of probability was used to verify the significant difference between treatments.

\section{RESULTS}

\subsection{Effect of some fertilization treatments on vegetative growth}

In the two seasons, plant length and plant fresh weight were significantly increased by all treatments of foliar spraying with potassien as compared with using chicken manure alone (Table 2). Meanwhile, plants treated with potassien plus chicken manure had significantly greater fresh weight than those obtained by using chemical fertilizers in the first year, but the other treatments with potassien, i.e. T5 (chicken manure+ potassifag + potassien) and T8 (chicken manure + phosphorien + potassien) gave greater plant fresh weight than in mineral fertilization in both seasons, without significant differences among these treatments. On the other hand, number of branches/plant was not affected by any treatment. pea plants with organic manure alone. Furthermore, all treatments of potassien, i.e., T3 (organic fertilizer + potassien), T5 (organic fertilizer + potassifag + potassien) and T8 (organic fertilizer + phosphorien + potassien) significantly exceeded mineral fertilization in the leaf contents of chlorophyll.

Organic fertilizer + potassifag + potassien (T5) significantly increased shoot dry mater $(\%)$ in both seasons as compared with using organic fertilizer alone. Different fertilizer treatments significantly influenced the $\mathrm{N}$ and $\mathrm{K}$ contents in plants, but had no influence on the $\mathrm{P}$ content. T5 (organic fertilizer + potassifag + potassien) and T8 (organic fertilizer ${ }_{+}$phosphorien ${ }_{+}$potassien) in both seasons as well as T3 (organic fertilizer + potassien) and $\mathrm{T} 1$ (mineral fertilizer) in the first season markedly raised $\mathrm{N}$ content in the plants as compared with using organic fertilizer alone. Also, T8 (organic fertilizer $_{+}$phosphorien ${ }_{+}$potassien) in both seasons and T5 (organic fertilizer + potassifag + potassien) in the first season significantly enhanced plant content of $\mathrm{K}$, as compared with using organic fertilizer alone. Moreover, T5 (organic fertilizer + potassifag + potassien) in the first season, and T8 (organic ertilizer + phosphorien + potassien)

Table (2): Effect of fertilization treatments on vegetative growth of garden peas.

\begin{tabular}{|l|l|l|l|l|l|l|}
\hline \multicolumn{1}{|c|}{ Treatments } & \multicolumn{3}{|c|}{2013 season } & \multicolumn{3}{c|}{2014 season } \\
\hline & $\begin{array}{l}\text { Plant } \\
\text { fresh } \\
\text { weight }(\mathrm{g})\end{array}$ & $\begin{array}{l}\text { Plant } \\
\text { length } \\
\text { (cm) }\end{array}$ & $\begin{array}{l}\text { No. of } \\
\text { branches } \\
\text { /plant }\end{array}$ & $\begin{array}{l}\text { Plant } \\
\text { fresh } \\
\text { weight }(\mathrm{g})\end{array}$ & $\begin{array}{l}\text { Plant } \\
\text { length cm) }\end{array}$ & $\begin{array}{l}\text { No. of } \\
\text { branches } \\
\text { /plant }\end{array}$ \\
\hline Mineral fertilizers (T1) & $\mathbf{3 1 . 4 0}$ & $\mathbf{5 9 . 3 8}$ & $\mathbf{2 . 0 0}$ & $\mathbf{2 9 . 0 7}$ & $\mathbf{6 2 . 0 4}$ & $\mathbf{1 . 4 6}$ \\
\hline Organic fertilizer (T2) & $\mathbf{2 9 . 7 3}$ & $\mathbf{5 3 . 0 4}$ & $\mathbf{1 . 7 9}$ & $\mathbf{2 2 . 4 5}$ & $\mathbf{5 6 . 8 8}$ & 1.17 \\
\hline Organic fertilizer + Potassien (T3) & $\mathbf{3 6 . 9 9}$ & $\mathbf{6 1 . 6 3}$ & $\mathbf{2 . 1 5}$ & $\mathbf{2 6 . 8 6}$ & $\mathbf{6 3 . 9 0}$ & $\mathbf{1 . 3 3}$ \\
\hline Organic fertilizer + Potassifag (T4) & $\mathbf{2 7 . 5 1}$ & $\mathbf{5 5 . 5 2}$ & $\mathbf{1 . 9 8}$ & $\mathbf{2 2 . 9 0}$ & $\mathbf{5 7 . 4 7}$ & $\mathbf{1 . 3 3}$ \\
\hline Organic fertilizer + Potassifag + Potassien (T5) & $\mathbf{3 5 . 4 2}$ & $\mathbf{5 9 . 4 5}$ & $\mathbf{2 . 0 6}$ & $\mathbf{2 6 . 6 3}$ & $\mathbf{6 2 . 7 5}$ & $\mathbf{1 . 3 4}$ \\
\hline Organic fertilizer + Phosphorien (T6) & $\mathbf{2 7 . 7 0}$ & $\mathbf{5 7 . 5 8}$ & $\mathbf{1 . 8 8}$ & $\mathbf{2 3 . 4 4}$ & $\mathbf{5 8 . 9 2}$ & $\mathbf{1 . 2 5}$ \\
\hline Organic fertilizer + Phosphorien + Potassifag (T7) & $\mathbf{2 7 . 9 4}$ & $\mathbf{5 3 . 6 2}$ & $\mathbf{2 . 0 0}$ & $\mathbf{2 3 . 0 6}$ & $\mathbf{6 0 . 5 7}$ & $\mathbf{1 . 1 7}$ \\
\hline Organic fertilizer + Phosphorien + Potassien (T8) & $\mathbf{3 5 . 8 5}$ & $\mathbf{5 9 . 2 6}$ & $\mathbf{2 . 2 1}$ & $\mathbf{2 6 . 9 4}$ & $\mathbf{6 2 . 3 3}$ & $\mathbf{1 . 4 2}$ \\
\hline L.S.D. at 5\% & $\mathbf{5 . 0 5}$ & $\mathbf{7 . 6 7}$ & NS & $\mathbf{6 . 5 8}$ & $\mathbf{8 . 2 6}$ & NS \\
\hline
\end{tabular}

\subsection{Effect of fertilization treatments on some chemical contents of shoots}

The chemical contents (chlorophyll, dry matter, $\mathrm{N}$ and $\mathrm{K}$ ) of shoots were found statistically significant due to different fertilization treatments (Tables 3 and 4).

Except fertilization with organic fertilizer + phosphorien, all fertilization treatments increased chlorophyll content as compared with fertilizing
In the second season significantly increased $\mathrm{K}$ and $\mathrm{N}$ concentrations in the plant as compared to $\mathrm{T} 1$ (mineral fertilizer).

\subsection{Effect of fertilization treatments on yield and yield components}

Using T5 (organic fertilizer + potassifag + potassien), T8 (organic fertilizer + phosphorien + potassien) and T1 (mineral fertilizer) for pea plants fertilization led to obtaining higher values of 
Table (3): Effect of fertilization treatments on some chemical contents of garden pea shoots (season 2013 ).

\begin{tabular}{|c|c|c|c|c|c|}
\hline Treatments & $\begin{array}{c}\text { Chlorophyll } \\
\text { (SPAD) }\end{array}$ & $\begin{array}{c}\text { Plant shoot dry } \\
\text { matter }(\%)\end{array}$ & $\begin{array}{c}\text { Nitrogen } \\
(\%)\end{array}$ & $\begin{array}{l}\text { Phosphorus } \\
(\%)\end{array}$ & $\begin{array}{l}\text { Potassium } \\
(\%)\end{array}$ \\
\hline Mineral fertilizers (T1) & 30.63 & 20.43 & 2.015 & 0.20 & 1.80 \\
\hline Organic fertilizer (T2) & 25.20 & 19.88 & 1.750 & 0.19 & 1.69 \\
\hline Organic fertilizer + Potassien $(\mathrm{T} 3)$ & 36.06 & 21.11 & 2.060 & 0.18 & 1.83 \\
\hline Organic fertilizer + Potassifag (T4) & 28.42 & 20.81 & 1.690 & 0.21 & 1.79 \\
\hline Organic fertilizer + Potassifag + Potassien & 37.21 & 21.90 & 2.082 & $\mathbf{0 . 1 8}$ & 1.98 \\
\hline Organic fertilizer + Phosphorien (T6) & 26.44 & 20.26 & 1.707 & $\mathbf{0 . 1 7}$ & 1.69 \\
\hline Organic fertilizer+ Phosphorien + Potassifag & 28.56 & 19.66 & 1.777 & $\mathbf{0 . 2 0}$ & 1.85 \\
\hline Organic fertilizer + Phosphorien + Potassien & 34.27 & 20.30 & 2.135 & 0.22 & 1.90 \\
\hline L.S.D. at 5\% & 2.84 & 1.80 & 0.132 & NS & 0.15 \\
\hline
\end{tabular}

Table (4): Effect of fertilization treatments on chemical contents of garden pea shoots (season 2014).

\begin{tabular}{|c|c|c|c|c|c|}
\hline Treatments & $\begin{array}{c}\text { Chlorophyll } \\
\text { (SPAD) }\end{array}$ & $\begin{array}{c}\text { Plant shoot dry } \\
\text { matter }(\%)\end{array}$ & $\begin{array}{c}\text { Nitrogen } \\
(\%)\end{array}$ & $\begin{array}{c}\text { Phosphorus } \\
(\%)\end{array}$ & $\begin{array}{c}\text { Potassium } \\
(\%)\end{array}$ \\
\hline Mineral fertilizers (T1) & 34.19 & 20.74 & 1.970 & 0.21 & 1.685 \\
\hline Organic fertilizer (T2) & 24.54 & 19.90 & 1.865 & 0.19 & 1.610 \\
\hline Organic fertilizer + Potassien (T3) & 36.96 & 21.53 & 2.020 & 0.18 & 1.780 \\
\hline Organic fertilizer + Potassifag (T4) & 36.12 & 21.59 & 1.835 & 0.22 & 1.645 \\
\hline Organic fertilizer + Potassifag + Potassien & 36.61 & 21.96 & 2.102 & 0.20 & $\mathbf{1 . 7 5 5}$ \\
\hline Organic fertilizer + Phosphorien (T6) & 26.67 & 20.17 & 1.918 & 0.19 & 1.693 \\
\hline Organic fertilizer + Phosphorien + Potassifag & 32.76 & 21.68 & 1.923 & 0.21 & 1.788 \\
\hline Organic fertilizer + Phosphorien + Potassien & 37.22 & 20.20 & 2.370 & 0.24 & 1.813 \\
\hline L.S.D. at $5 \%$ & 2.17 & $\mathbf{N S}$ & $\mathbf{0 . 1 9}$ & $\mathbf{N S}$ & 0.203 \\
\hline
\end{tabular}


weight and number of pods yield per plant in both seasons, as compared with values obtained in the chicken manure treatment alon. T 5 and T 8 gave also significantly higher total pod yield (ton/fed) over chicken manure alone. On the other hand, these two treatments gave relatively higher values of yield per plant and per feddan than using chemical fertilizers, but without significant differences between these two treatments and the chemical fertilizer.

Weight of 100 green seeds was significantly higher in plants received organic fertilizer + potassifag (T4) or organic fertilizer + phosphorien + potassien (T8) in the first season and organic fertilizer + potassifag + potassien (T5) in both seasons, as compared with those received organic fertilizer alone (Table 5).

Generally, the highest value of pods yield (ton/fed) was obtained by using T8 treatment (organic fertilizer + phosphorien + potassien), while using T5 (organic fertilizer + potassifag + potassien) led to getting the highest value of weight of green pods per plant. The differences between those two treatments and using organic fertilizer alone were significant. Using organic fertilizer + phosphorien + potassien (T8) gave 25.8 and $17.3 \%$ increase in the green pods yield (ton/fed) over using organic fertilizer alone, in the first and second seasons, respectively, while T5 treatment (organic fertilizer + potassifag + potassien) achieved 23.9 and $14.3 \%$ increase in green pods yield (ton/fed) in the first and second season, respectively, over using organic fertilizer alone. Concerning the increase in weight of green pods /plant, the treatments organic fertilizer + potassifag + potassien (T5) and organic fertilizer + phosphorien + potassien (T8) achieved 22.5 and 17.3 , in the first season, and 14.4 and $11.2 \%$, respectively, in the second season over using organic fertilizer alone.

\subsection{Effect of fertilization treatments on green pods characters}

T5 (organic fertilizer + potassifag + potassien) treatment exhibited the highest values of pod weight, pod length and number of seeds/pod, which were also significantly higher than respective values obtained with organic manure alone in the two seasons (Table 6).

\subsection{Effect of fertilization treatments on chemical contents of green seeds}

The different fertilizer treatments significantly affected dry matter, protein percentage and total sugars in fresh seeds in both seasons (Table 7). Chemical fertilizers and all potassien treatments, i.e organic fertilizer + potassien (T3), organic fertilizer + potassifag + potassien (T5) and organic fertilizer + phosphorien + potassien $(\mathrm{T} 8)$ caused significantly increase in protein percentage over organic manure alone. Except organic fertilizer + phosphorien (T7) and chemical fertilization (T1), all other treatments increased total sugars in green seeds as compared with organic fertilizer alone. Moreover, green seeds obtained from plants fertilized with organic fertilizer + potassifag + potassien (T5) or organic fertilizer + phosphorien + potassifag (T7) in both seasons or with organic fertilizer + phosphorien + potassien $(\mathrm{T} 8)$ in the first season contained higher percentage of total sugars as compared to chemical fertilization. Compared with organic fertilizer alone the treatments of organic fertilizer + potassien (T3), organic fertilizer + potassifag + potassien (T5) and organic fertilizer + phosphorien + potassien $(\mathrm{T} 8)$ in both seasons, as well as mineral fertilizers (T1), in the first season and organic fertilizer + phosphorien + potassifag (T7) in the second season caused significant increase in the percentage of pod dry matter mater.

\section{DISCUSSION}

The vegetative growth traits of green pea i.e., plant length and fresh weight/plant were significantly increased by all treatments of foliar spraying with potassien as compared with using chicken manure alone, in the two seasons (Table 2).

Furthermore, all treatments of potassien, i.e., T3 (organic fertilizer + potassien), T 5 (organic fertilizer + potassifag + potassien) and T8 (organic fertilizer + phosphorien + potassien) significantly exceeded mineral fertilization in the leaf contents of chlorophyll.

T 5 (organic fertilizer + potassifag + potassien) and T8 (organic fertilizer + phosphorien + potassien) in both seasons as well as T3 (organic fertilizer + potassien), and mineral fertilizer in the first season markedly raised $\mathrm{N}$ content in the shoots as compared with organic fertilizer. Also, T8 (organic fertilizer + phosphorien + potassien) in both seasons and T 5 (organic fertilizer + potassifag + potassien) in the first season significantly 
Table (5): Effect of fertilization treatments on yield and yield components of garden peas.

\begin{tabular}{|c|c|c|c|c|c|c|c|c|}
\hline \multirow[t]{2}{*}{ Treatments } & \multicolumn{4}{|c|}{2013} & \multicolumn{4}{|c|}{2014} \\
\hline & $\begin{array}{c}\text { Number } \\
\text { of green } \\
\text { pods } \\
\text { /plant }\end{array}$ & $\begin{array}{c}\text { Weight } \\
\text { of green } \\
\text { pods } \\
\text { (g/plant) }\end{array}$ & $\begin{array}{c}\text { Green } \\
\text { pods } \\
\text { yield } \\
\text { (ton/fed) }\end{array}$ & $\begin{array}{l}\text { Weight } \\
\text { of } 100 \\
\text { green } \\
\text { seeds }\end{array}$ & $\begin{array}{c}\text { Number } \\
\text { of green } \\
\text { pods } \\
\text { /plan }\end{array}$ & $\begin{array}{c}\text { Weight } \\
\text { of green } \\
\text { pods } \\
\text { (g/plant) }\end{array}$ & $\begin{array}{c}\text { Green } \\
\text { pods } \\
\text { yield } \\
\text { (ton/fed) }\end{array}$ & $\begin{array}{l}\text { Weight } \\
\text { of } 100 \\
\text { green } \\
\text { seeds }\end{array}$ \\
\hline Mineral fertilizers (T1) & 10.20 & 53.84 & 3.374 & 51.61 & 11.35 & 52.01 & 3.586 & 53.65 \\
\hline Organic fertilizer (T2) & 9.50 & 44.73 & 3.140 & 49.58 & 10.43 & 43.30 & 3.238 & 49.58 \\
\hline Organic fertilizer + Potassien (T3) & 9.50 & 49.80 & 3.364 & 52.02 & 11.22 & 51.30 & 3.526 & 52.63 \\
\hline Organic fertilizer + Potassifag (T4) & 9.60 & 47.96 & 3.358 & $\mathbf{5 2 . 8 3}$ & 11.22 & 50.23 & 3.463 & $\mathbf{5 0 . 8 0}$ \\
\hline Organic fertilizer + Potassifag + Potassien (T5) & $\mathbf{1 0 , 2 0}$ & 58.84 & 3.891 & 54.24 & 11.60 & 57.11 & 3.753 & $\mathbf{5 3 . 8 5}$ \\
\hline Organic fertilizer + Phosphorien (T6) & 9.65 & 45.49 & 3.271 & $\mathbf{5 0 . 4 0}$ & 11.50 & 48.76 & 3.262 & 49.58 \\
\hline Organic fertilizer+Phosphorien+ Potassifag (T7) & 9.50 & 47.97 & 3.401 & 51.00 & 11.50 & 50.90 & 3.468 & 50.19 \\
\hline Organic fertilizer + Phosphorien + Potassien (T8) & 10.25 & 53.66 & 3.951 & 52.42 & 11.35 & 52.61 & 3.797 & 51.41 \\
\hline L.S.D. at $5 \%$ & 1.2 & 4.02 & 0.707 & 2.644 & 0.8 & 5.65 & 0.458 & 3.292 \\
\hline
\end{tabular}


Table (6): Effect of fertilization treatments on green pods characters of garden peas.

\begin{tabular}{|c|c|c|c|c|c|c|c|c|}
\hline \multirow[t]{2}{*}{ Treatments } & \multicolumn{4}{|c|}{2013} & \multicolumn{4}{|c|}{2014} \\
\hline & $\begin{array}{l}\text { Pod } \\
\text { weight } \\
\text { (g) }\end{array}$ & $\begin{array}{l}\text { Pod } \\
\text { length }\end{array}$ & $\begin{array}{l}\text { Pod } \\
\text { diameter }\end{array}$ & $\begin{array}{l}\text { Number of } \\
\text { seeds/pod }\end{array}$ & $\begin{array}{l}\text { Pod } \\
\text { weight } \\
\text { (g) }\end{array}$ & $\begin{array}{l}\text { Pod } \\
\text { length }\end{array}$ & $\begin{array}{l}\text { Pod } \\
\text { diameter }\end{array}$ & $\begin{array}{l}\text { Number of } \\
\text { seeds/pod }\end{array}$ \\
\hline Mineral fertilizers (T1) & 5.24 & 9.00 & 1.27 & $\mathbf{7 . 5 0}$ & 4.63 & 8.90 & 1.32 & 7.25 \\
\hline Organic fertilizer (T2) & 4.68 & 8.16 & 1.22 & 6.95 & 4.15 & 8.53 & 1.22 & 6.60 \\
\hline Organic fertilizer + Potassien (T3) & 5.24 & 8.43 & 1.28 & 7.65 & 4.57 & 7.95 & 1.30 & 6.90 \\
\hline Organic fertilizer + Potassifag (T4) & 5.00 & 8.04 & 1.30 & 7.15 & 4.48 & 8.00 & 1.25 & 7.10 \\
\hline Organic fertilizer + Potassifag + Potassien (T5) & 5.77 & 9.79 & 1.28 & 8.25 & 4.92 & 9.50 & 1.33 & 7.35 \\
\hline Organic fertilizer + Phosphorien (T6) & 4.77 & 8.88 & 1.24 & 7.20 & 4.26 & 8.34 & 1.22 & 6.80 \\
\hline Organic fertilizer + Phosphorien + Potassifag (T7) & 5.10 & 8.40 & 1.31 & 7.15 & 4.44 & 8.53 & 1.24 & 7.25 \\
\hline Organic fertilizer + Phosphorien + Potassien (T8) & 5.26 & 8.65 & 1.26 & 7.53 & 4.73 & 8.34 & 1.27 & 7.30 \\
\hline L.S.D. at $5 \%$ & 1.07 & 1.33 & NS & 0.81 & 0.67 & 0.85 & NS & 0.72 \\
\hline
\end{tabular}


Table (7): Effect of fertilization treatments on the chemical contents of green seeds of garden peas.

\begin{tabular}{|c|c|c|c|c|c|c|}
\hline \multirow{2}{*}{ Treatments } & \multicolumn{3}{|c|}{2013} & \multicolumn{3}{|c|}{2014} \\
\hline & $\begin{array}{l}\text { Pod dry } \\
\text { matter }(\%)\end{array}$ & $\begin{array}{l}\text { Protein } \\
(\%)\end{array}$ & $\begin{array}{l}\text { Total } \\
\text { sugars }(\%)\end{array}$ & $\begin{array}{l}\text { Pod dry } \\
\text { matter }(\%)\end{array}$ & $\begin{array}{l}\text { Protein } \\
(\%)\end{array}$ & $\begin{array}{l}\text { Total } \\
\text { sugars }(\%)\end{array}$ \\
\hline Mineral fertilizers (T1) & 23.74 & 18.979 & 16.07 & 19.55 & 18.556 & 16.86 \\
\hline Organic fertilizer (T2) & 21.20 & 17.924 & 14.62 & $\mathbf{1 7 . 8 0}$ & 18.036 & 14.55 \\
\hline Organic fertilizer + Potassien (T3) & 23.73 & 19.520 & 17.28 & 20.57 & 19.141 & 18.07 \\
\hline Organic fertilizer + Potassifag (T4) & 22.32 & 17.719 & 16.90 & 18.34 & $\mathbf{1 8 . 0 4 5}$ & $\mathbf{1 7 . 2 2}$ \\
\hline Organic fertilizer + Potassifag + Potassien (T5) & 24.03 & 21.270 & 17.77 & 21.27 & 18.9 & 20.46 \\
\hline Organic fertilizer + Phosphorien (T6) & 20.82 & $\mathbf{1 7 . 9 3 0}$ & 14.37 & 16.52 & 17.90 & 14.37 \\
\hline Organic fertilizer + Phosphorien + Potassifag (T7) & 21.52 & 17.756 & 18.31 & 21.01 & 1.813 & 18.17 \\
\hline Organic fertilizer + Phosphorien + Potassien (T8) & 23.49 & 18.990 & 17.73 & 21.63 & 18.863 & 17.65 \\
\hline L.S.D. at 5\% & 1.99 & 0.870 & $\mathbf{1 . 5 0}$ & 1.94 & 0.245 & 1.31 \\
\hline
\end{tabular}


enhanced shoot content of K. Potassien consists of $30 \% \mathrm{~K}$ and $8 \% \mathrm{~N}$. Nitrogen is necessary for the formation of amino acids, the building blocks of protein and essential for plant cell division. It is vital for plant growth. It is also an essential constituent of chlorophyll and directly involved in photosynthesis and it comprises $40 \%$ to $50 \%$ of the dry matter of protoplasm (Roy et al., 2006). So, the greater vegetative growth that was recorded with using potassien may be due to the presence of nitrogen in potassien. It is well known that nitrogen causes enhancement in chlorophyll content and nitrogen percentage in shoots. Furthermore, most potassien treatments showed significantly higher values of vegetative growth, $\mathrm{N}$ and dry matter percentage as compared to mineral fertilizer. Foliar application of nutrients is a more suitable option compared with soil fertilization when the roots cannot provide the necessary nutrients. Other advantages are quick compensation of nutrient deficiency and application of lesser rates thus, reducing toxicity arises from excessive accumulation of elements , preventing nutrients fixation in the soil and reducing problem of soil compactness (Wojcik, 2004).

Also, T8 (organic fertilizer + phosphorien + potassien) in both seasons and T5 (organic fertilizer + potassifag + potassien) in the first season significantly enhanced shoot content of K. These results may be due to presence of $\mathrm{K}$ at $20 \%$ in potassien.

Using T5 (organic fertilizer + potassifag + potassien) and T8 (organic fertilizer + phosphorien + potassien) in both seasons led to obtaining significantly higher values of weight and number of pods yield per plant, and total pod yield as compared with pea plants received chicken manure alone. On the other hand, these two treatments gave relatively higher values of yield per plant and per feddan than using chemical fertilizers, but without significant differences between these two treatments and the chemical fertilizer.

Average weight of green pods and weight of 100 green seeds were significantly higher in plants received organic fertilizer + potassifag or organic fertilizer + phosphorien + potassien in the first season or organic fertilizer + potassifag + potassien in both seasons, as compared with those received organic fertilizer alone (Table 5). The increase occurred in the total yield and its components might be attributed to the increase in vegetative growth traits (Tables 3 and 4). Foliar application of potassium nitrate significantly increased vegetative growth, chlorophyll contents yield and yield components of cucumber (Al-Hamzawi, 2010) and potato (Ben Dkhil et al ., 2011) as well as leaf and fruit contents of N, P and $\mathrm{K}$ of cucumber (Al-Hamzawi, 2010).

The highest value of pods yield (ton/fed) was obtained by using the treatment of organic fertilizer + phosphorien + potassien $(\mathrm{T} 8)$, while using organic fertilizer + potassifag + potassien (T5) led to obtaining the highest value of weight of green pods per plant. T8 (organic fertilizer + phosphorien + potassien) gave 25.8 and $17.3 \%$ increase in the green pods yield /fed over using organic fertilizer alone, in the first and second season, respectively, while the increase in green pods yield /fed over using organic fertilizer alone due to using the treatment organic fertilizer + potassifag + potassien (T5) was 23.9 and 14.3\%, in the first and second season, respectively. Concerning the increase in weight of green pods (g/plant), T5 (organic fertilizer + potassifag + potassien) and T8 (organic fertilizer + phosphorien +potassien) achieved 31.5 and $20.0 \%$, respectively, in the first season, and 31.8 and 21.5 $\%$, respectively, in the second season over using organic fertilizer alone. The high total yield per feddan, which resulted from using T8 (organic fertilizer + phosphorien + potassifag) may be attributed to the presence of phosphate-dissolving bacteria (PDB) which take part in biological control against soil borne phytopathogens (Vassilev et al., 2006). Many previous studies have proved that inoculation with PDB improved plant growth and yield of many crops. In this regard BDB remarkably enhanced plant growth of cowpea (Linu et al., 2009), dry beans (Tozlu et al., 2012), mung bean (Walpola and Yoon, 2013) and garden pea plants grown on sandy calcareous soil (Howladar, et al., 2014), and increased yield of strawberry (Gunes et al., 2009) and dry beans (Tozlu et al., 2012). Similarly, inoculation of seeds and seedling treatments of plants with potassium solubilize bacteria (KDB) generally showed significant beneficial effects on growth and yield of pepper and cucumber (Han et al., 2006), tomato (Lin et al., 2002), eggplant (Ramarethinam and Chandra 2005; Han and Lee, 
2005.), okra (Prajapati et al., 2013) and mungebean (Prajapati, 2016) over uninoculated control in the presence of feldspar. The increase in plant growth and yield due to using $\mathrm{BDB}$ and KDB is attributed to solubilizing the insoluble form of phosphate (Khan et al., 2007) and potassium (Meena et al., 2014) to soluble forms, respectively. In the present study, it was clear that inoculation of pea seeds with phospherien, that contains phosphate dissolving bacteria (Bacillus magatherum) and potassifag that contains potasium dissolving bacteria (Bacillus circulance) in presence of chicken manure did not improve plant growth or yield of pea plant as compared with using chicken manure alone. The inconsistency and variability in the plant responses to phosphate and potassium dissolving bacteria have been previously attributed to adverse conditions such as interaction of rhizospheric organisms, physical and chemical conditions of the soil (e.g., low or high $\mathrm{pH}$ ), poor ability of the PGPR strain to colonize the plant roots, environmental factors including high or low mean temperatures, and, low rainfall during the growing season, as well as to host cultivars. Many or all these factors could be involved in the lack of consistent responses to application of biofertilizers (Fuentes-Ramirez and Caballero-Mellado, 2006).

Chemical fertilizers and all potassien treatments, i.e organic fertilizer + potassien (T3), organic fertilizer + potassifag + potassien (T5) and organic fertilizer + phosphorien + potassien $(\mathrm{T} 8)$ caused significant increase in protein percentage over organic manure alone. These results may be attributed to the presence of mineral nitrogen in available and quick form in both mineral fertilizer and potassien. All treatments of potassien and potassifage cause remarkable increases in the dry matter percentage and reducing sugars content of green seeds. Potassien has potassium at $20 \%$ and potassifag contains potassium solubilize bacteria, which transfer the insoluble form of potassium to soluble forms (Meena et al., 2014). The present results may be attributed to the role of potassium in the formation of carbohydrates and translocation of photo assimilates into source organs.

\section{Conclusion}

The integrated fertilization management consisting of chicken manure at 5 ton/fed plus mineral foliar fertilization (using potassien) and biofertization (using potassifag or phosphorien) can be recommended for pea production in clay soil instead of using soil application of mineral fertilization with the purpose of reducing soil pollution with chemical fertilizers.

\section{REFERENCES}

A. O. A. C. methods (1990). Official method of analysis of official agriculture chemist, $15^{\text {th }}$ Ed. Washington, D.C., USA.

Abou-el-Seoud I. I. A and Abdel-Megeed A. (2012). Impact of rock materials and biofertilizations on $\mathrm{P}$ and $\mathrm{K}$ availability for maize (Zea maize) under calcareous soil conditions. Saudi J. Biol. Sci., 19, 55-63.

Al-Hamzawi M.K.A. (2010) . Effect of calcium nitrate, potassium nitrate and anfaton on growth and storability of plastic houses cucumber (Cucutnis sativus L. cv. AlHytham). Amer. J. Plant Physiol., 5 (5): 278290.

Awasthi R., Tewari R. and Nayyar, H. (2011). Synergy between plants and P-solubilizing microbesin soils: effects on growth AvilésVázquez, K., Samulon, A. and Perfecto, I. (2007). Organic and physiology of crops. Int'l. Res. J. Micro., 2:484-503.

Badgley C., Moghtader J., Quintero E., Zakem E., Chappell M. J., Avilés-Vázquez K , Samulon, A. and Perfecto I. (2007). Organic agriculture and the global food supply. Renew. Agric. Food Sys., 22: 86108.

Ben Dkhil B., Denden M. and Aboud S. (2011). Foliar potassium fertilization and its effect on growth, yield and quality of potato grown under loam-sandy soil and semi-arid conditions. Inter. J. Agric. Res., 6 (7): 593-600.

Chen X. P., Ji H. J. and Zhang F. S. (2000). The problems and countermeasures of vegetable fertilization in Beijing. $I n$ : $\mathrm{Li}, \mathrm{X}$. L. and Zhang, F. S. (eds.), Fertilizing for Sustainable Production of High Quality Vegetable. China Agricultural University Press, Beijing., china, pp. 270-277.

Cottenie A., Verloo M., Kiekens L., Velghe G. and Camerlynck R. (1982). Chemical analysis of plant and soil. Laboratory of analytical and agrochemistry, State Univ. Ghent, Belgium, pp 100-129 
El-Tantawy M. E. and Mohamed M. A. N. (2009). Effect of inoculation with phosphate solubilizing bacteria on the tomato rhizosphere colonization process, plant growth and yield under organic and inorganic fertilization. J. App. Sci. Res., 5(9): 1117-1131.

El-Waraky Y. B., Masoud A.M. and Knany R.E. (2013). Effect of balanced manuring by mineral NPK and bio-fertilizer on peas productivity and protein content. J. Plant Produ., Mansoura Univ., 4 (12):813-1827.

Francis C.A (2004). Organic farming. In. H. Daniel (ed.), Encyclopedia of Soils in the Environment, vol. 3, 77-84. Elsevier, Oxford, UK.

Fuentes-Ramirez, L.E and Caballero-Mellado, J. (2006). Bacterial biofertilizers. In: Z. A. Siddiqui (ed.), PGPR: Biocontrol and Biofertilization, 143-172., Published by Springer, P.O. Box 17, 3300 AA Dordrecht, The Netherlands.

Gomez K. A. and Gomez A. A. (1984). Statistical Procedures for Agricultural Research $2^{\text {nd }}$ ed. John Wiley and sons Pub. Canada.

Gunes A., Ataoglu N., Turan M., Esitken A. and Ketterings Q. M. (2009).Effects of phosphate-solubilizing microorganisms on strawberry yield and nutrient concentrations. J. Plant Nutr. Soil Sci., 172, 385-392.

Hamayun M., Khan S.A., Khan A. L., Shinwari Z. K., Ahmad N., Kim Y. and Lee I. J. (2011). Effect of foliar and soil application of nitrogen, phosphorus and potassium on yield components of lentil. Pak. J. Bot., 43(1): 391-396.

Hamid A. (1991). Foliar fertilization of nitrogen in mung bean: influence of rate and frequency of application. Ann. Bangladesh Agric., 1 (1): 33-39.

Han H.S. and Lee K.D. (2005). Phosphate and potassium solubilizing bacteria effect on mineral uptake, soil availability and growth of eggplant. Res. J. Agric. Biol. Sci., 1(2): 176- 180.

Han H. S., Supanjani E. and Lee K. D. (2006). Effect of co-inoculation with phosphate and potassium solubilizing bacteria on mineral uptake and growth of pepper and cucumber. Plant Soil Environ., 52 (3): 30-136.
Hartz T. K., Mitchell J. P. and Giannini C. (2000). Nitrogen and carbon mineralization dynamics of manures and compost. Hort. Sci., 35:209-212.

Hellal F. A., Zewainy R. M., Khalil A. A. and Ragab A. A. M. (2014). Effect of organic and bio-fertilizer management practices on nutrient availability and uptake by Faba bean- Maize sequence. American-Eurasian J. Sustain. Agric., 8(5): 35-42.

Hesse P.R. (1971). A text book of soil chemical analysis. Juan Murry (Publisher) Ltd., London, U K.

Howladar S.M., Osman A.S., Rady M. M. and Al-Zahrani H.S. (2014). Magnesium foliar application and phosphorien soil inoculation positively affect Pisum sativum 1. plants grown on sandy calcareous soil. Int'l. J. Bio., Biomolec., Agric., Food and Biotech. Engin., 8:(5)436-440.

Khan M.S., Zaidi A. and Wani P.A. (2007). Role of phosphate-solubilizing microorganisms in sustainable agriculture - a review. Agron. Sustain. Dev., 27:29-43.

Lin Q., Rao Z., Sun Y., Yao J. and Xing L. (2002) Identification and practical application of silicate-dissolving bacteria. Agric. Sci. China, 1:81-85.

Linu M.S., Stephen J. and Jisha M.S. (2009). Phosphate solubilizing gluconacetobacter sp., Burkholderia sp. and their potential interaction with cowpea (Vigna unguiculata (L.) Walp.). Int'l. J. Agric. Res. 4:79-87.

Liu Z. H. (2000). Characteristics of Greenhouse Vegetable Soil and Reasonable Fertilization in Shandong Province (in Chinese, with English abstract). Ph. D. Dissertation, China Agric. Univ., China.

Liu Z.H., Jiang L.H., Li X.L., Hardter R. , Zhang W.J., Zhang Y.L. and Zheng D.F. (2008). Effect of $\mathrm{N}$ and $\mathrm{K}$ fertilizers on yield and quality of greenhouse vegetable crops. Pedosphere, 18, (4): 496-502.

Makasheva R.K.H. (1983). The pea. Oxonion Press Pvt. Ltd. New Delhi. India, pp. 267.

Malusá E. and Vassilev N. (2014). A contribution to set a legal framework for biofertilisers. Appl. Micro. Biotech., 98: 6599-6607.

Meena V. S., Mauryaa B.R. and Verma J. P. (2014). Does a rhizospheric microorganism 
enhance $\mathrm{K}$ availability in agricultural soils?

Microb. Res. 169:337-347.

Mohapatra B., Verma D. K. , Sen A., Bipin B. P. and Asthir B. (2013). Biofertilizers- a gateway to sustainable agriculture. Popular Kheti, 1: 1(4):97-106.

Peterburgski A.V. (1968) Handbook of Agronomic Chemistry. Kolop Publishing House, Moscow, Russia.

Prajapati K. (2016). Impact of potassium solubilizing bacteria on growth and yield of mungebean Vigna radiate. Biotechnology, 6:(2) 390-392.

Prajapati K, Sharma M.C. and Modi H.A. (2013) Growth promoting effect of potassium solubilizing microorganisms on Abelmoscus esculantus. Int'1. J Agric. Sci., 3:181-188.

Ramarethinam S. and Chandra K. (2005) Studies on the effect of potash solubilizing/mobilizing bacteria Frateuria aurantia on brinjal growth and yield. Pestology, 11: 35-39.

Rizk F.A. (2002). Bioorganic and chemical fertilizer as affected the productivity of eggplant (Solanum melogena, L.). J. Agric. Sci. Mansoura Univ., 27 (12): 8477-8491.

Roy R.N., Finck A., Blair G.J. and Tandon H.L.S. (2006). Plant nutrition for food security: a guide for integrated nutrient management "Chapter 3: Plant nutrients and basics of plant nutrition". Rome: Food and Agriculture Organization of the United Nations. pp. 25-42.

Shukla R., Sharma Y. K. and Shukla A. K. (2014). Molecular mechanism of nutrient uptake in plants. Int'l. J. Curr. Res. Ac. Rev., 2 (12):142-154.

Singh G., Biswas D. R. and Marwah T. S. (2010). Mobilization of potassium from waste mica by plant growth promoting rhizobacteria and its assimilation by maize
(Zea mays) and wheat (Triticum aestivum L.). J. Plant. Nutr., 33:1236-51.

Tozlu E., Karagöz K. G., Babagil E., Dizikisa T. and Kotan R. (2012). Effect of some plant growth promoting bacteria on yield, yield components of dry bean (Phaseolus vulgaris L. cv. Aras 98) Atatürk Univ. J. Agric. Fac., 43 (2):101-106.

Warman P. R. and Havard K. A. (1997). Yield, vitamin and mineral contents of organically and conventionally grown carrots and cabbage. Agric., Ecosy. and Environ., 61:155- 162 .

Wojcik P. (2004). Uptake of mineral nutrients from foliar fertilization (review). J. Fruit Ornam. Plant Res., Special ed., 12:201-218.

Vassilev N., Vassileva M. and Nikolaeva I. (2006). Simultaneous P-solubilizing and biocontrol activity of microorganisms: potentials and future trends. Appl. Microbiol. Biotechnol., 71: 137-144.

Walpola B. C. and Yoon M. H. (2013). Phosphate solubilizing bacteria:Assessment of their effect on growth promotion and phosphorous uptake of mung bean (Vigna radiata [L.] R. Wilczek). Chilean J. Agric. Res. 73(3):275-281.

Yadava U. L. (1986). A rapid and non- destructive method to determine chlorophyll in intact leaves. Hort. Sci., 21:1449-1450.

Youssef G.H., Seddik W.M.A. and Osman M.A. (2010). Efficiency of natural minerals in presence of different nitrogen forms and potassium dissolving bacteria on peanut and sesame yields. J. Am. Sci., 6 (11):647-660.

Zhang A., Zhao G., Gao T., Wang W., Li J. and Zhang S. (2013). Solubilization of insoluble potassium and phosphate by Paenibacillus kribensis CX-7: a soil microorganism with biological control potential. Afr. J. Micro. Res., 7 (1):41-47. 
تأثير بعض معاملات التسميد المتكامل على نمو وإنتاجية وجودة نباتات البسلة

\author{
شيرين سيا فتحى السيد \\ قسم الخضر ـ كلية الزراعةـ جامعة القاهرة ــ الجيزة ــ مصر
}

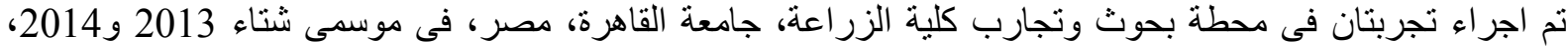

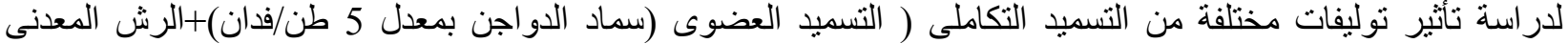

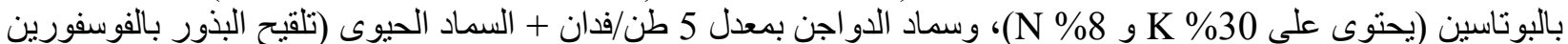

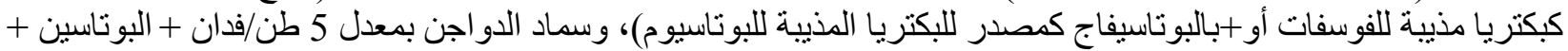

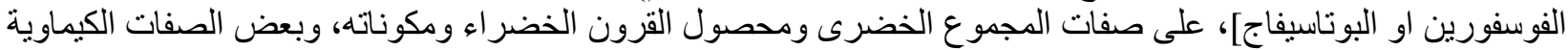

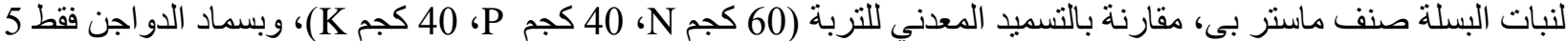

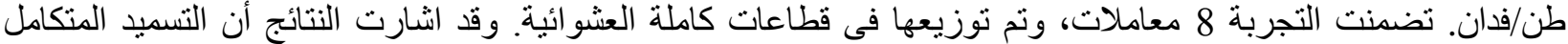

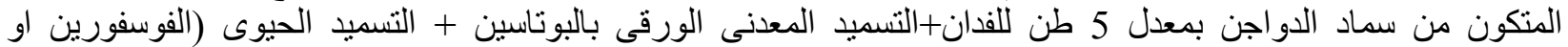

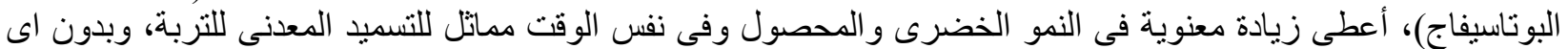

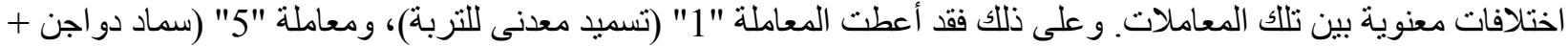

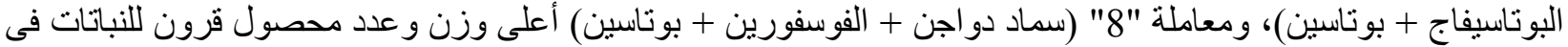

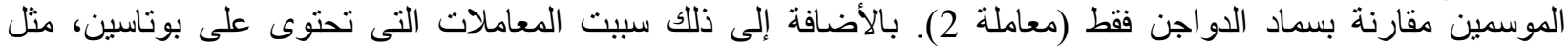

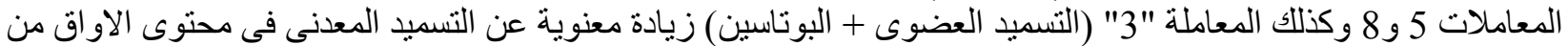

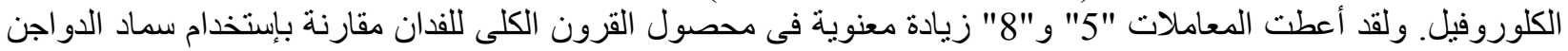

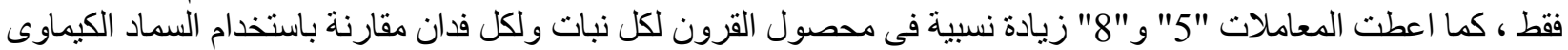

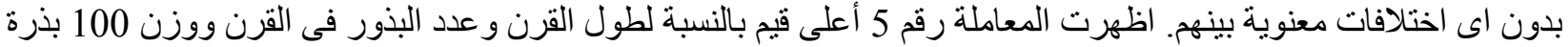

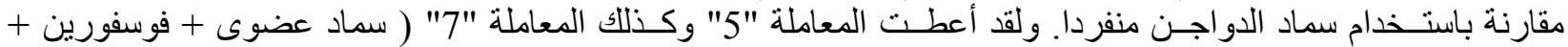

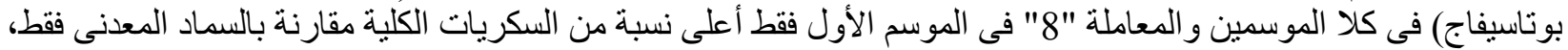

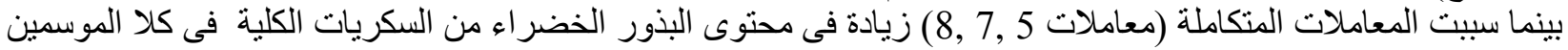

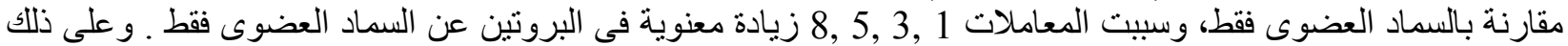

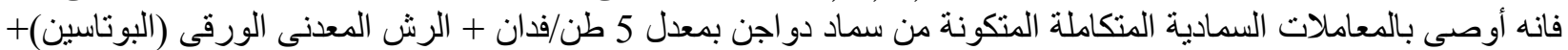

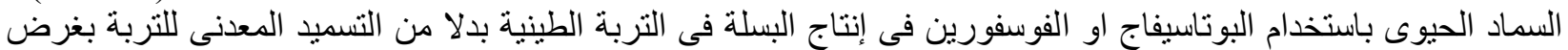

تقليل التلوث الترية بالأسمدة الكيماوية. لكية.

المجلة العلمية لكلية الزراعة - جامعة القاهرة ـ المجلا (68) العدد الثاني (أبريل 2017): 141-182. 